\title{
Major Tumor Suppressor and Oncogenic Non-Coding RNAs: Clinical Relevance in Lung Cancer
}

\author{
Kentaro Inamura
}

Division of Pathology, The Cancer Institute, Japanese Foundation for Cancer Research, 3-8-31 Ariake, Koto-ku, Tokyo 135-8550, Japan; kentaro.inamura@jfcr.or.jp; Tel.: +81-3-3570-0111 (ext. 5604); Fax: +81-3-3570-0558

Academic Editor: Alexander E. Kalyuzhny

Received: 20 April 2017; Accepted: 5 May 2017; Published: 9 May 2017

\begin{abstract}
Lung cancer is the leading cause of cancer deaths worldwide, yet there remains a lack of specific and sensitive tools for early diagnosis and targeted therapies. High-throughput sequencing techniques revealed that non-coding RNAs (ncRNAs), e.g., microRNAs and long ncRNAs (lncRNAs), represent more than $80 \%$ of the transcribed human genome. Emerging evidence suggests that microRNAs and lncRNAs regulate target genes and play an important role in biological processes and signaling pathways in malignancies, including lung cancer. In lung cancer, several tumor suppressor/oncogenic microRNAs and lncRNAs function as biomarkers for metastasis and prognosis, and thus may serve as therapeutic tools. In this review, recent work on microRNAs and lncRNAs is introduced and briefly summarized with a focus on potential biological and therapeutic applications.
\end{abstract}

Keywords: adenocarcinoma; carcinoma; carcinogenesis; histology; long non-coding RNA; miRNA; molecular pathology; oncology

\section{Introduction}

Lung cancer is the leading cause of cancer deaths among males in both developing and developed countries, and it has outpaced breast cancer as the leading cause of cancer deaths in females in developed countries [1]. Lung cancers are categorized into two main histological groups: small cell lung cancer (SCLC, 15\% of all lung cancers) and non-SCLC (NSCLC, 85\% of all lung cancers). NSCLCs are further subcategorized into three major histological subtypes: adenocarcinoma, squamous cell carcinoma (SqCC), and large cell carcinoma. Lung cancers are heterogeneous diseases characterized by distinct epigenetic and genetic abnormalities, even within the same histological type [2-18]. Although extensive efforts to develop molecular-targeted drugs are ongoing [19-27], no targeted therapies are available for a number of lung cancer patients. Although techniques and strategies for the early detection of lung cancer have improved, most lung cancers are still diagnosed at advanced stages. Therefore, the identification of novel diagnostic biomarkers and therapeutic strategies is a prerequisite for the management of lung cancer.

In recent years, the dysregulation of microRNAs and long non-coding RNAs (lncRNAs) has been highlighted as potential diagnostic and therapeutic tools in malignancies, including lung cancer [28-49]. Indeed, microRNAs and lncRNAs regulate a number of target genes, play an important role in lung carcinogenesis, and serve as potential diagnostic and therapeutic tools in lung cancer [37-49].

In this review, recent work on lncRNAs and microRNAs in lung cancer is summarized with a focus on their biological and therapeutic applications.

\section{Non-Coding RNA}

Emerging evidence from the human genome sequencing projects suggests that more than $80 \%$ of the human genome is actively transcribed into RNA, even though less than $3 \%$ of the human 
genome encodes translated proteins [50,51]. RNAs that do not yield coding proteins are collectively referred to as non-coding RNAs (ncRNA). These ncRNAs are divided into housekeeping ncRNAs and regulatory ncRNAs. Housekeeping ncRNAs include transfer RNAs (tRNAs) and ribosomal RNAs (rRNAs). Regulatory ncRNAs are generally transcribed in a location- and time-dependent fashion. Regulatory ncRNAs can be further divided into two groups based on their size: small ncRNAs (shorter than 200 nucleotides) and lncRNAs (200 nucleotides or longer). Small ncRNAs contain microRNAs, small nucleolar RNAs (snoRNAs), small interfering RNAs (siRNAs), small nuclear RNAs (snRNAs), and PIWI-interacting RNAs (piRNAs) (Figure 1) [49-51].

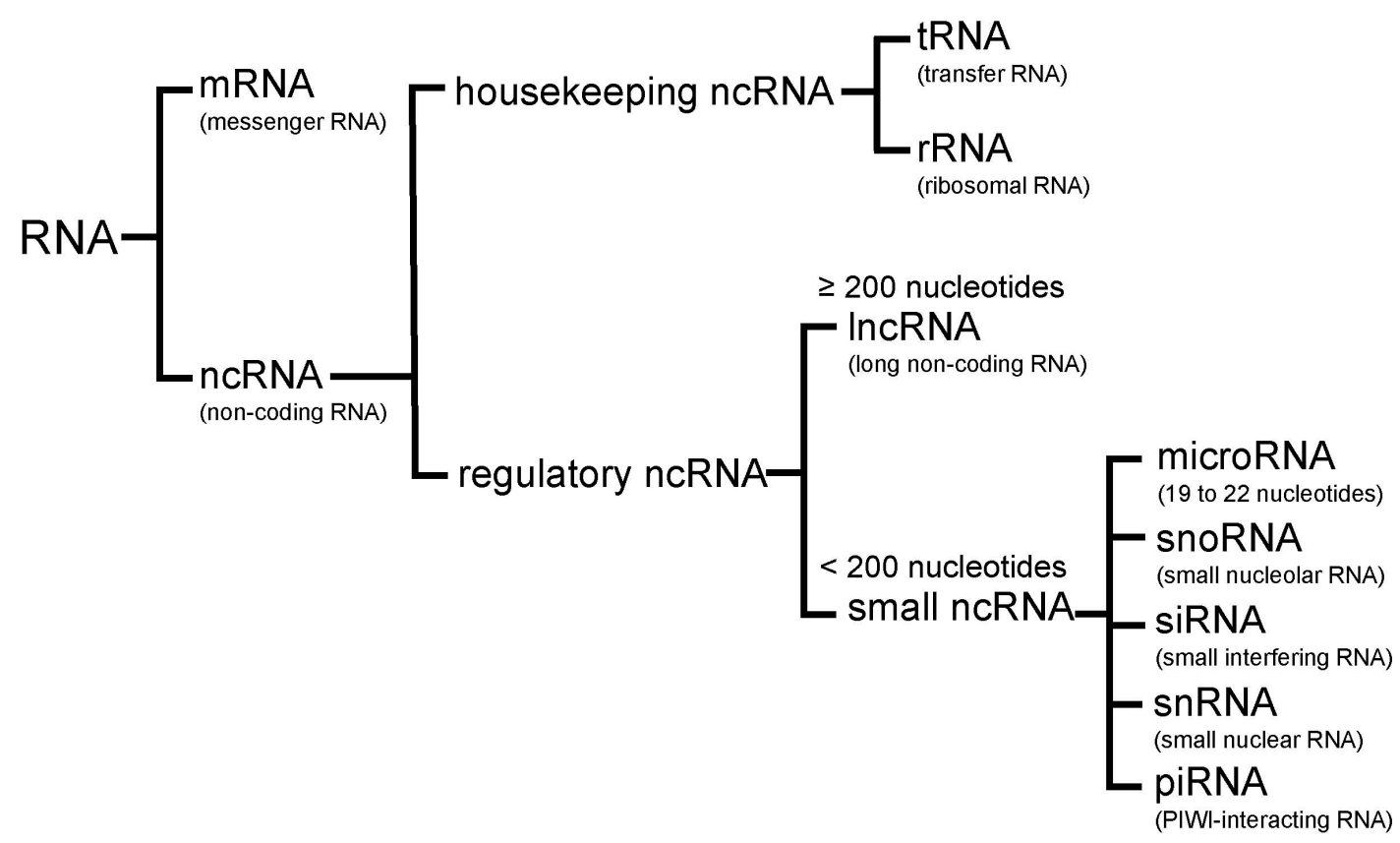

Figure 1. RNA categories. RNAs are divided into two major classes: messenger RNA (mRNA) and non-coding RNA (ncRNA). NcRNAs include housekeeping ncRNA, which consists of transfer RNA (tRNA) and ribosomal RNA (rRNA), and regulatory ncRNA. Regulatory ncRNAs are classified into long ncRNA (lncRNA) and small ncRNA. Small ncRNAs are subclassified into microRNA, small nucleolar RNA (snoRNA), small interfering RNA (siRNA), small nuclear RNA (snRNA), and PIWI-interacting RNA (piRNA).

\subsection{MicroRNAs}

MicroRNAs are small single stranded ncRNAs (19 to 22 nucleotides in length) that are highly conserved among different organisms. MicroRNAs play important regulatory roles in animals and plants by targeting messenger RNAs (mRNAs) for translational repression or degradation. MicroRNAs comprise one of the most abundant classes of gene regulatory molecules and therefore influence the output of many protein-coding genes [52]. MicroRNAs have the potential to serve as biomarkers and therapeutic tools for different cancer subtypes, as classified by origin, histology, aggressiveness, or chemosensitivity [37-40,45-49]. Importantly, in comparison to mRNAs, microRNAs are markedly less degraded in formalin-fixed paraffin-embedded (FFPE) samples, which are typically collected and stored in hospitals. Therefore, the easy availability of archived FFPE samples and the ability to accurately measure microRNA expression enables translation studies on microRNAs. Unlike mRNA, microRNAs exist in tissues and body fluids, such as blood and sputum. Thus, the characteristics of microRNAs support the development of liquid biopsies. 


\section{2. $\operatorname{LncRNAs}$}

LncRNAs are largely polyadenylated and comprise more than 200-nucleotide or longer transcripts. LncRNAs are also engaged in gene expression via transcriptional and epigenetic regulation, imprinting, splicing, and subcellular transport. Although the major mechanism of lncRNAs is the regulation of expression of neighboring genes, lncRNAs also serve as scaffold for protein-protein interactions or decoys to proteins [53]. Additionally, IncRNAs can regulate kinase functions. LncRNA NBR2 engages a metabolic checkpoint by regulating AMP-activated protein kinase (AMPK) under energy stress [54]. Accumulating evidence suggests that IncRNAs play a role in fundamental biological functions, and dysregulation of lncRNAs contributes to cancer development, progression, and metastasis in many malignancies, including lung cancer [41-44]. Therefore, lncRNAs can be used as therapeutic targets.

Notably, lncRNAs can serve as minimally invasive and sensitive molecular markers for the screening and early diagnosis of lung cancer [55]. Peng et al. constructed a serum ncRNA panel (miR-1254, miR-485-5p, miR-574-5p, and lncRNA MALAT1), and tested whether the ncRNA panel could distinguish NSCLC patient samples from controls. Their results indicated that the four ncRNA panel can serve as a convenient tool for early NSCLC diagnosis [55]. LncRNAs are stable even in body fluids and show tissue-specific expression. These characteristic features make lncRNAs attractive as potential biomarkers in liquid biopsies.

\section{Experimental Techniques to Detect MicroRNAs and LncRNAs}

The golden standard for experimental techniques to detect microRNAs and lncRNAs is considered to be reverse transcriptase quantitative polymerase chain reaction (RT-qPCR). However, regarding the extraction methods, kits, controls, and quantification methods, no standards exist, which can affect the results [56]. Nonetheless, the traditional amplification method, RT-qPCR, has been well established and widely used because of its higher sensitivity, wider dynamic range, and higher precision [57]. Compared to the methods of quantifying lncRNAs, those of quantifying microRNAs have advanced. Because the traditional amplification-based method is not enough to fulfill the various requests of laboratory and clinical applications, RT-free qPCR, isothermal amplification methods, and some cross-platforms combined with amplification-based methods have been developed. Among them, the traditional RT-qPCR and cross-platforms including PCR-based arrays and next generation sequencing have been well designed and are useful [57].

\section{MicroRNAs and Lung Cancer}

A number of studies have identified aberrant microRNA expression in lung cancer, thus supporting microRNAs involvement in lung carcinogenesis [37-40]. MicroRNAs play important regulatory roles in lung cancer, including both tumor suppression and oncogenesis. Table 1 and Figure 2 show the major tumor suppressor and oncogenic microRNAs in lung cancer. In this section, tumor suppressor and oncogenic microRNAs are introduced with suggestions on their potential utility in the diagnosis and treatment of lung cancer.

\subsection{Tumor Suppressor MicroRNAs}

\subsubsection{Let-7}

Let-7 is one of the earliest identified tumor suppressor microRNAs in lung cancer, and its decreased expression is associated with poor prognosis [58]. Let-7 expression is reduced in adenocarcinoma in situ (AIS) when compared with adjacent normal lung tissue, indicating that let-7 expression is decreased during the early phase of lung carcinogenesis [59]. Let-7 inhibits the expression of oncogenes involved in cell proliferation, such as $M Y C, R A S$, and HMGA2 [60,61]. Interestingly, let-7 directly down-regulates DICER1 expression, indicating that the global production of microRNAs may be regulated by let-7 [62]. Furthermore, let-7 regulates the cell cycle by inhibiting CDK6 expression [61]. Recently, Zhou et al. showed that miR-203 played an important role in promoting the apoptosis and inhibiting the cell 
proliferation of lung cancer by downregulating LIN28B and upregulating let-7 biogenesis. Their results demonstrate a novel regulatory network among miR-203, LIN28B, and let-7 in lung cancer [63].

\subsection{2. $M i R-34$}

MiR-34 is directly transcribed by TP53, responding to DNA damage and oncogenic stress. MiR-34 is an important component of TP53 tumor suppressor function [30]. Decreased expression of miR-34 in lung cancer induces increased-expression of miR-34 target genes, such as BCL2, MET, PDGFRA, and PDGFRB, which leads to TNF-related apoptosis-inducing ligand (TRAIL)-induced cell death. The down-regulation of miR-34 upregulates MET and BCL2, which leads to cell proliferation [64-66]. A recent study found that tumor PD-L1 expression is regulated by TP53 via miR-34 [67]. MiR-34, which is transcribed by TP53, directly binds to the PD-L1 $3^{\prime}$ untranslated region and downregulates it. The identified TP53/miR-34/PD-L1 axis deserves consideration for the improvement of emerging immunotherapy.

\subsection{3. $M i R-200$}

MiR-200 plays a critical role in the inducement of epithelial-mesenchymal transition (EMT). Decreased expression of miR-200 up-regulates its target genes, namely CDH1 (also known as E-cadherin), VIM (also known as vimentin), ZEB1, and ZEB2, which leads to EMT as lung cancer progresses [68,69]. Zhang et al. evaluated the effect of decitabine, a DNA methyltransferase inhibitor, on TGF- $\beta 1$-induced EMT in NSCLC cells, considering the involvement of the miR-200/ZEB axis. Decitabine reversed TGF- 31 -induced EMT in NSCLC cells by downregulating ZEB1 and ZEB2 epigenetically by miR-200. They found that epigenetic regulation of the miR-200/ZEB axis is responsible for EMT induction by TGF- $\beta 1$ in NSCLC cells, and that decitabine inhibits EMT in NSCLC cells via miR-200 [70].

\subsection{4. $M i R-126$}

The decreased expression of miR-126 in lung cancer reduces its target PIK3R2 and the PTEN/PI3K/AKT signaling pathway is therefore influenced, leading to the suppression of cell growth, migration, and invasion [71]. Recently, An et al. found that Matrine, which is an active component of traditional Chinese medicine, induces cell cycle arrest and apoptosis by upregulating miR-126 in NSCLC cells [72].

\subsection{5. $M i R-195$}

MiR-195 expression is lower in NSCLC than in non-cancerous normal tissues and low miR-195 expression has been associated with unfavorable overall survival of patients with NSCLC. MiR-195 suppresses cancer growth and is associated with lower mortality in several cancers, including NSCLC. CHEK1 is a direct target of miR-195, which results in decreased CHEK1 expression in lung cancer. Up-regulation of CHEK1 by reduced expression of miR-195 promotes cell proliferation, migration, and invasion, and is associated with a higher overall mortality in lung cancer [73].

\subsection{Oncogenic MicroRNAs}

\subsection{1. $M i R-21$}

MiR-21 represents one of the most famous oncogenic microRNAs, and it is over-expressed in a number of malignancies, including lung cancer. High expression of miR-21 predicts recurrence and higher mortality in NSCLC [74]. Furthermore, abundant miR-21 exists in body fluids, being one of the most promising microRNAs in patients with lung cancer [49]. MiR-21 promotes carcinogenesis via inhibition of negative regulators of RAS/MEK/ERK signaling pathway and apoptosis suppression. Over-expressed miR-21 down-regulates the expression of PDCD4, PTEN, SOCS1, SOCS6, and TPM1, thus promoting cell proliferation and migration and inhibiting apoptosis [75-78]. MiR-21 has been used as a biomarker to predict therapeutic responses to cisplatin [79]. Xu et al. conducted in vitro 
and in vivo experiments and demonstrated that downregulation of $m i R-21$ suppression increased the cisplatin sensitivity of NSCLC. Regarding radiosensitivity, downregulation of miR-21 sensitized radio-resistant NSCLC A549 cells to ionizing radiation through the inhibition of the PI3K/AKT signaling pathway [80].

In addition, certain drugs were reported to downregulate miR-21. Solasodine is an aglycone of solamargine and solasonine, which are the major solasodine glycosides in eggplant. Shen et al. demonstrated that solasodine inhibited the invasion of NSCLC A549 cells via the downregulation of miR-21 and matrix metalloprotease (MMP) expression [81]. Triptolide is isolated from Tripterygium wilfordii plants and used in traditional Chinese medicine. Lie et al. demonstrated that triptolide reduced proliferation and enhanced the apoptosis of NSCLC PC-9 cells in a PTEN-dependent manner by downregulating $m i R-21$ [82].

\subsection{2. $M i R-155$}

As with $m i R-21, m i R-155$ is an important oncogenic microRNA that has been suggested as a therapeutic target in NSCLC [74,78,83-85]. As with $m i R-21, m i R-155$ is also a promising circulating microRNA in patients with lung cancer [49]. MiR-155 directly targets TP53, whereas TP53 directly regulates the expression of $m i R-155$. This $m i R-155 /$ TP53 feedback loop is involved in chemotherapy resistance [85]. Xue et al. reported that $m i R-21$ and $m i R-155$ promote the progression of NSCLCs, in part by downregulating SOCS1, SOCS6, and PTEN, all of which are tumor suppressor genes. Thus, the combined inhibition of $m i R-21$ and $m i R-155$ may improve the treatment of NSCLCs [78].

\subsubsection{MiR-17-92}

The miR-17-92 intronic cluster comprises seven different microRNAs (miR-17-5p, miR-17-3p, $m i R-18 a, m i R-19 a, m i R-19 b-1, m i R-20 a$, and $m i R-92)$ and resides in intron 3 of the C13orf 25 gene at $13 q 31.3$ [86]. Overexpression of the $m i R-17-92$ cluster with occasional gene amplification plays a role in the lung carcinogenesis, especially SCLC [86]. The MiR-17-92 cluster down-regulates HIF1A, E2F1, and PTEN, which leads to cell proliferation and cancer progression $[87,88]$. Matsubara et al. reported that antisense oligonucleotides against $m i R-17-5 p$ and $m i R-20 a$ within the $m i R-17-92$ cluster induced apoptosis in lung cancers overexpressing $m i R-17-92$ [87]. Recently, Li et al. found that FLI1, which is an Ets transcription factor family member and known as a major driver of hematological malignancies, plays an important role in tumor progression in SCLC. Furthermore, they uncovered FLI1 as a critical driving factor that promotes cancer growth in SCLC through the miR-17-92 pathway [89]. FLI1 and miR-17-92 may serve as promising therapeutic targets to improve the treatment of SCLCs.

\subsubsection{MiR-221/222}

Both $m i R-221$ and $m i R-222$ have an identical seed sequence and are predicted to have overlapping targets. MiR-221/222 is associated with tyrosine kinase inhibitor (TKI)-resistant NSCLCs. Garofalo et al. reported that TKI-resistance was overcome by anti-miR-221/222 and anti-miR-30c, which recovered BCL2L11 expression and increased the gefitinib sensitivity of NSCLCs, thus providing a microRNA-mediated therapeutic approach for TKI-resistant NSCLCs [90]. MiR-221/222 influences lung carcinogenesis by down-regulating TIMP3 and PTEN tumor suppressor genes [91,92]. Up-regulated $m i R-221 / 222$ promotes cell migration and suppresses apoptosis by targeting TIMP3 and PTEN.

\subsubsection{MiR-31}

MiR-31 targets BAP1, which is a necessary nuclear-located deubiquitinating enzyme that acts as a tumor suppressor in lung cancer. Increased expression of $m i R-31$ reduced the BAP1 expression, leading to cell proliferation and suppressed apoptosis [93]. Edmonds et al. reported that $m i R-31$ directly downregulated six negative regulators of the RAS/MAPK signaling pathway (SPRED1, SPRED2, SPRY1, SPRY3, SPRY4, and RASA1) and promoted mutant KRAS-mediated oncogenesis [94]. 
Although many studies suggest that $m i R-31$ is an oncogenic microRNA, there are reports suggesting that miR-31 functions as a tumor suppressor in lung cancer $[95,96]$. Xu et al. reported that the downregulation of miR-31 enhanced lung cancer proliferation and migration by upregulating $\mathrm{HuR}$, an RNA binding protein [95]. Okudela et al. reported that restoration and knockdown of miR-31 in lung cancer cell lines attenuated their growth activities and enhanced oncogenic phenotypes, respectively, suggesting that $m i R-31$ acts as a tumor suppressor $[95,96]$. Further research is required to determine whether $m i R-31$ plays a pleiotropic role in individual tumors.

Table 1. Tumor suppressor and oncogenic microRNAs in lung cancer.

\begin{tabular}{|c|c|c|}
\hline MicroRNA & Expression & Affected Biological Processes and Target Genes \\
\hline \multicolumn{3}{|c|}{$\begin{array}{l}\text { Tumor suppressor } \\
\text { microRNAs }\end{array}$} \\
\hline let-7 & Decreased & $\begin{array}{l}\text { i) Cell proliferation }(M Y C, R A S, H M G A 2)[60,61] \\
\text { ii) MicroRNA biogenesis (DICER1) [62] } \\
\text { iii) Cell cycle regulation (CDK6) [61] }\end{array}$ \\
\hline$m i R-34$ & Decreased & $\begin{array}{l}\text { TRAIL-induced cell death and cell proliferation (BCL2, MET, PDGFRA, } \\
P D G F R B)[64-66]\end{array}$ \\
\hline $\operatorname{miR}-200$ & Decreased & Promotion of EMT and metastasis (CDH1, VIM, ZEB1, ZEB2) $[68,69]$ \\
\hline$m i R-126$ & Decreased & $\begin{array}{l}\text { Cell proliferation, migration, and invasion through PTEN/PI3K/AKT } \\
\text { pathway (PIK3R2) [71] }\end{array}$ \\
\hline $\operatorname{miR}-195$ & Decreased & Cell proliferation, migration, and invasion (CHEK1) [73] \\
\hline \multicolumn{3}{|l|}{$\begin{array}{l}\text { Oncogenic } \\
\text { microRNAs }\end{array}$} \\
\hline$m i R-21$ & Increased & $\begin{array}{l}\text { Cell proliferation, migration, and apoptosis (PDCD4, PTEN, SOCS1, } \\
\text { SOCS6, TPM1) [75-78] }\end{array}$ \\
\hline $\operatorname{miR}-155$ & Increased & $\begin{array}{l}\text { Resistance to chemotherapy (TP53) [85] } \\
\text { Cell proliferation and apoptosis (SOCS1, SOCS6, PTEN) [78] }\end{array}$ \\
\hline$m i R-17-92$ & Increased & Carcinogenesis and cell proliferation (HIF1A, E2F1, PTEN) $[87,88]$ \\
\hline$m i R-221 / 222$ & Increased & Cell migration and apoptosis (PTEN, TIMP3) [91,92] \\
\hline$m i R-31$ & Increased & $\begin{array}{l}\text { Cell proliferation and apoptosis (BAP1) [93] } \\
\text { Promotion of KRAS/MAPK signaling (SPRED1, SPRED2, SPRY1, } \\
\text { SPRY3, SPRY4, RASA1) [94] }\end{array}$ \\
\hline
\end{tabular}

EMT, epithelial-mesenchymal transition. TRAIL, TNF-related apoptosis-inducing ligand.

Tumor suppressor microRNAs

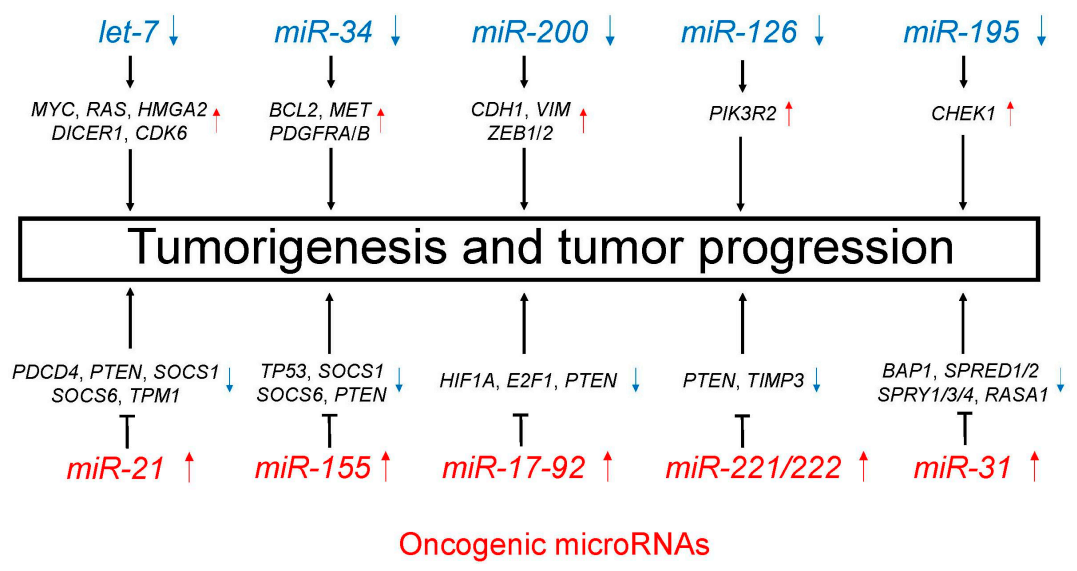

Figure 2. Tumor suppressor (blue)/oncogenic (red) microRNAs regulate unique target genes. This regulation by tumor suppressor/oncogenic microRNAs leads to tumorigenesis and tumor progression. 


\section{LncRNAs and Lung Cancer}

Emerging evidence suggests the aberrant expression of lncRNAs in lung cancer, thus indicating a role for lncRNAs in lung carcinogenesis [41-44]. Many lncRNAs play critical regulatory roles in lung cancer as tumor suppressor or oncogenic lncRNAs. Table 2 and Figure 3 summarize major tumor suppressor and oncogenic lncRNAs in lung cancer.

\subsection{Tumor Suppressor LncRNAs}

\subsubsection{MEG3}

MEG3, which is located on $14 \mathrm{q} 32.2$, is a maternally expressed imprinted lncRNA found in a variety of normal tissues. MEG3 expression was reduced in several cancers, and up-regulation of $M E G 3$ inhibits tumor growth [97]. Lu et al. reported that the expression of MEG3 was down-regulated in NSCLCs when compared to adjacent normal lung tissues; furthermore, decreased expression of MEG3 was associated with a relatively poor prognosis [98]. MEG3 inhibits NSCLC cell proliferation and induces apoptosis by up-regulating TP53 expression [97,98]. As with NSCLC, downregulated MEG3 in breast cancer also regulates proliferation, migration, and invasion by depending on the transcriptional activity of TP53 [99].

\subsubsection{GAS6-AS1}

GAS6-AS1, which is located on chromosome 13q34, is transcribed antisense to the GAS6 gene. Down-regulation of GAS6-AS1 promotes cancer progression in several malignancies, including lung cancer [100]. Han et al. demonstrated that GAS6-AS1 expression is lower in NSCLC than adjacent non-cancerous normal tissue and suggested downregulation of GAS6-AS1 as an independent biomarker for higher overall mortality in NSCLC patients [100]. Because the molecular mechanisms of GAS6-AS1-mediated NSCLC progression still remain elusive, further mechanical studies should be required.

\subsubsection{BANCR}

$B A N C R$ mediates cell growth by regulating cell-growth arrest, leading to the reduction of cancer incidence. The expression of BANCR is significantly down-regulated in NSCLC tissues when compared to adjacent non-cancerous normal lung tissues, and the lower BANCR expression has been associated with higher mortality in NSCLC patients [101]. Although the mechanical explanation why BANCR suppresses invasiveness and metastasis of NSCLCs remains unclear, it is likely associated with EMT inhibition. Loss of BANCR expression reduces CDH1 (also known as E-cadherin) expression and induces CDH2 (also known as N-cadherin), VIM (also known as vimentin), and MMPs [101]. Thus, $B A N C R$ is also a potential target of lncRNA-mediated therapeutics.

\subsubsection{PANDAR}

PANDAR, which is located on chromosome $6 \mathrm{q} 21.2$, is a tumor suppressor lncRNA. Han et al. reported that decreased expression of PANDAR was associated with higher overall mortality in NSCLC patients. A direct transcription target of PANDAR includes TP53 in NSCLC cells, and PANDAR affects cell apoptosis by regulating BCL2 [102]. Because PANDR is a direct transcriptional target of TP53 in NSCLC, overexpression of PANDR could inhibit the proliferation of NSCLC cells.

\subsection{Oncogenic LncRNAs}

\subsubsection{MALAT1}

MALAT1, also known as NEAT2, is a promising lncRNA, and is a candidate of biomarker in liquid biopsy for the diagnosis of NSCLCs. Furthermore, high MALAT1 expression in FFPE specimens indicates a higher mortality in NSCLCs and experimentally promotes cell proliferation, 
migration, metastasis, and EMT [103-105]. One possible mechanistic explanation for the oncogenic activity of MALAT1 is that MALAT1 participates in aberrant alternative splicing, which results in the dysregulated expression of genes, including B-MYB transcription factor [106]. Recently, Wang et al. conducted a follow-up study for 538 patients of NSCLC, and genetic variant rs3200401 in MALAT1 was then genotyped among this population. They demonstrated that the rs3200401 $\mathrm{T}$ allele located on the lncRNA MALAT1 was associated with lower mortality for patients with advanced lung adenocarcinoma [107].

\subsubsection{HOTAIR}

HOTAIR is a lncRNA, which is located downstream, in the antisense direction, of HOXC12 gene [108]. HOTAIR promotes the invasiveness and metastasis of several cancer types by recruiting PRC2 or chromatin reorganization [109]. Additionally, HOTAIR has been reported to participate in chemoresistance to cisplatin in lung adenocarcinoma [110]. Liu et al. also reported that elevated HOTAIR expression was associated with cisplatin resistance in NSCLC, and showed that HOTAIR expression was directly related to KLF4 expression, suggesting a new therapeutic target for drug-resistance patients with NSCLC [111].

\subsubsection{CCAT2}

CCAT2 is a novel lncRNA and its overexpression is associated with a number of cancers, including NSCLC. CCAT2 is highly expressed in NSCLCs, especially adenocarcinoma. According to a study using NSCLC cell lines by Qiu et al. [112], reducing CCAT2 expression by siRNA inhibits tumor proliferation and invasiveness in NSCLC cells. CCAT2 promotes cell migration by up-regulating MYC, miR-20a, and miR-17-5p through TCF7L2-mediated transcription in cell lines [113]. Recently, Zhao et al. showed that CCAT2 promotes tumorigenesis by overexpressing of Pokemon (also known as ZBTB7A) and suggested that the potential mechanism might relate to the Pokemon-related gene CDKN1A (also known as p21) [114].

Table 2. Tumor suppressor and oncogenic long non-coding RNAs (lncRNAs) in lung cancer.

\begin{tabular}{ccl}
\hline MicroRNA & Chromosome & \multicolumn{1}{c}{ Biological Processes } \\
\hline Tumor suppressor lncRNAs & & \\
\hline MEG3 & $14 \mathrm{q} 32.2$ & TP53 up-regulation [97,98] \\
\hline GAS6-AS1 & $13 \mathrm{q} 34$ & Unknown \\
\hline BANCR & $9 \mathrm{q} 21.12$ & EMT inhibition [101] \\
\hline PANDAR & $6 \mathrm{q} 21.2$ & Apoptosis by BCL2 down-regulation [102] \\
\hline Oncogenic lncRNAs & $11 \mathrm{q} 13.1$ & Cell proliferation, migration, metastasis, and EMT [105] \\
\hline MALAT1 & $12 \mathrm{q} 13.13$ & $\begin{array}{l}\text { Invasiveness and metastasis by recruiting PRC2 or } \\
\text { reorganizing chromatin [109] }\end{array}$ \\
\hline HOTAIR & $8 \mathrm{q} 24.21$ & $\begin{array}{l}\text { Cell migration by up-regulating of } M Y C, \text { miR-17-5p, } \\
\text { and miR-20a through TCF7L2-mediated transcription [113] }\end{array}$ \\
\hline
\end{tabular}

EMT, epithelial-mesenchymal transition; lncRNA, long non-coding RNA. 
Tumor suppressor long non-coding RNAs

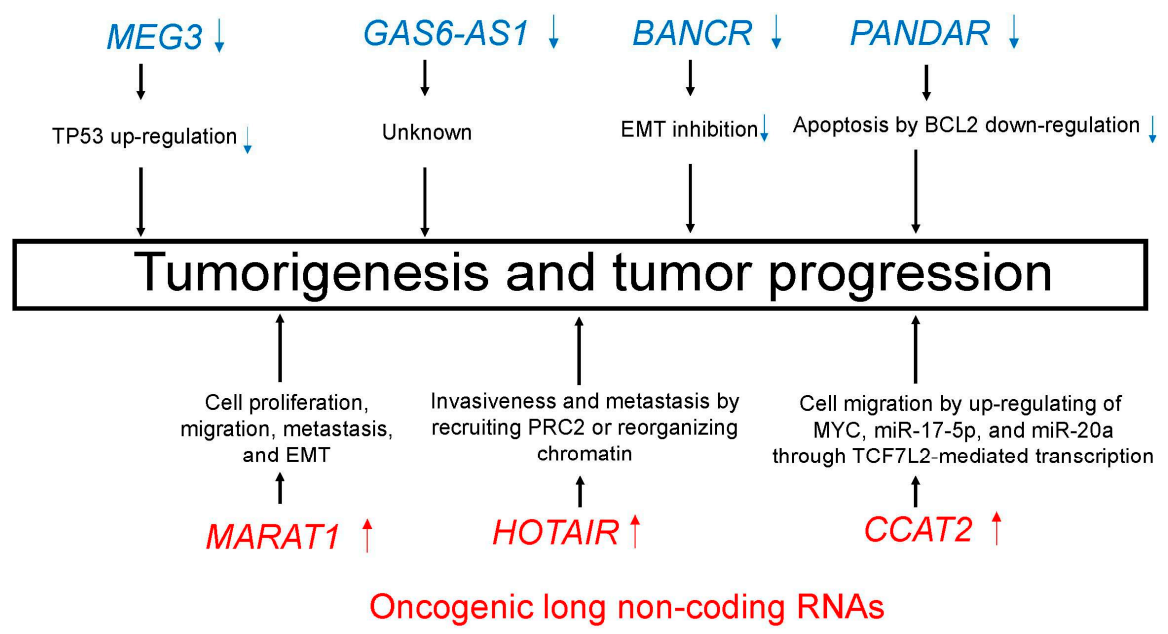

Figure 3. Tumor suppressor (blue)/oncogenic (red) long non-coding RNAs (lncRNAs) induce important processes that lead to tumorigenesis and tumor progression.

\section{Conclusions and Future Directions}

In this review, recent studies of microRNAs and lncRNAs in lung cancer are introduced with a focus on potential biological and therapeutic applications. Accumulating evidence suggests that microRNAs and lncRNAs represent very promising biomarkers in patients with NSCLC and will be markedly useful in non-invasive screening methods. MicroRNA- or lncRNA-mediated therapy for patients with lung cancer is also very promising. Further studies and clinical trials are needed to assess microRNA or lncRNA profiles as diagnostic markers and conduct microRNA- and lncRNA-based therapies in clinical practice.

Acknowledgments: This study was supported by JSPS KAKENHI Grant Number JP16K08679; and the Ministry of the Environment, Japan.

Author Contributions: Kentaro Inamura conceived the review, wrote the text, and created the tables and figure.

Conflicts of Interest: The author declares no conflicts of interest.

\section{References}

1. Torre, L.A.; Bray, F.; Siegel, R.L.; Ferlay, J.; Lortet-Tieulent, J.; Jemal, A. Global cancer statistics, 2012. CA Cancer J. Clin. 2015, 65, 87-108. [CrossRef] [PubMed]

2. Travis, W.D.; Brambilla, E.; Burke, A.P.; Marx, A.; Nicholson, A.G. WHO Classification of Tumours of the Lung, Pleura, Thymus and Heart, 4th ed.; IARC: Lyon, France, 2015.

3. The Cancer Genome Atlas Research Network. Comprehensive molecular profiling of lung adenocarcinoma. Nature 2014, 511, 543-550.

4. The Cancer Genome Atlas Research Network. Comprehensive genomic characterization of squamous cell lung cancers. Nature 2012, 489, 519-525.

5. George, J.; Lim, J.S.; Jang, S.J.; Cun, Y.; Ozretic, L.; Kong, G.; Leenders, F.; Lu, X.; Fernandez-Cuesta, L.; Bosco, G.; et al. Comprehensive genomic profiles of small cell lung cancer. Nature 2015, 524, 47-53. [CrossRef] [PubMed]

6. Rudin, C.M.; Durinck, S.; Stawiski, E.W.; Poirier, J.T.; Modrusan, Z.; Shames, D.S.; Bergbower, E.A.; Guan, Y.; Shin, J.; Guillory, J.; et al. Comprehensive genomic analysis identifies SOX2 as a frequently amplified gene in small-cell lung cancer. Nat. Genet. 2012, 44, 1111-1116. [CrossRef] [PubMed] 
7. Inamura, K.; Fujiwara, T.; Hoshida, Y.; Isagawa, T.; Jones, M.H.; Virtanen, C.; Shimane, M.; Satoh, Y.; Okumura, S.; Nakagawa, K.; et al. Two subclasses of lung squamous cell carcinoma with different gene expression profiles and prognosis identified by hierarchical clustering and non-negative matrix factorization. Oncogene 2005, 24, 7105-7113. [CrossRef] [PubMed]

8. Inamura, K.; Satoh, Y.; Okumura, S.; Nakagawa, K.; Tsuchiya, E.; Fukayama, M.; Ishikawa, Y. Pulmonary adenocarcinomas with enteric differentiation: Histologic and immunohistochemical characteristics compared with metastatic colorectal cancers and usual pulmonary adenocarcinomas. Am. J. Surg. Pathol. 2005, 29, 660-665. [CrossRef] [PubMed]

9. Shaw, A.T.; Yeap, B.Y.; Mino-Kenudson, M.; Digumarthy, S.R.; Costa, D.B.; Heist, R.S.; Solomon, B.; Stubbs, H.; Admane, S.; McDermott, U.; et al. Clinical features and outcome of patients with non-small-cell lung cancer who harbor EML4-ALK. J. Clin. Oncol. 2009, 27, 4247-4253. [CrossRef] [PubMed]

10. Takeuchi, K.; Soda, M.; Togashi, Y.; Suzuki, R.; Sakata, S.; Hatano, S.; Asaka, R.; Hamanaka, W.; Ninomiya, H.; Uehara, H.; et al. RET, ROS1 and ALK fusions in lung cancer. Nat. Med. 2012, 18, 378-381. [CrossRef] [PubMed]

11. Inamura, K.; Yokouchi, Y.; Sakakibara, R.; Kobayashi, M.; Subat, S.; Ninomiya, H.; Nagano, H.; Nomura, K.; Okumura, S.; Ishikawa, Y. Relationship of tumor PD-L1 expression with EGFR wild-type status and poor prognosis in lung adenocarcinoma. Jpn. J. Clin. Oncol. 2016, 46, 935-941. [CrossRef] [PubMed]

12. Brambilla, E.; Le Teuff, G.; Marguet, S.; Lantuejoul, S.; Dunant, A.; Graziano, S.; Pirker, R.; Douillard, J.Y.; Le Chevalier, T.; Filipits, M.; et al. Prognostic Effect of Tumor Lymphocytic Infiltration in Resectable Non-Small-Cell Lung Cancer. J. Clin. Oncol. 2016, 34, 1223-1230. [CrossRef] [PubMed]

13. Awad, M.M.; Oxnard, G.R.; Jackman, D.M.; Savukoski, D.O.; Hall, D.; Shivdasani, P.; Heng, J.C.; Dahlberg, S.E.; Janne, P.A.; Verma, S.; et al. MET Exon 14 Mutations in Non-Small-Cell Lung Cancer Are Associated With Advanced Age and Stage-Dependent MET Genomic Amplification and c-Met Overexpression. J. Clin. Oncol. 2016, 34, 721-730. [CrossRef] [PubMed]

14. Inamura, K.; Ninomiya, H.; Nomura, K.; Tsuchiya, E.; Satoh, Y.; Okumura, S.; Nakagawa, K.; Takata, A.; Kohyama, N.; Ishikawa, Y. Combined effects of asbestos and cigarette smoke on the development of lung adenocarcinoma: Different carcinogens may cause different genomic changes. Oncol. Rep. 2014, 32, 475-482. [CrossRef] [PubMed]

15. Celiktas, M.; Tanaka, I.; Chandra Tripathi, S.; Fahrmann, J.F.; Aguilar-Bonavides, C.; Villalobos, P.; Delgado, O.; Dhillon, D.; Dennison, J.B.; Ostrin, E.J.; et al. Role of CPS1 in Cell Growth, Metabolism, and Prognosis in LKB1-Inactivated Lung Adenocarcinoma. J. Natl. Cancer Inst. 2017, 109, 1-9. [CrossRef] [PubMed]

16. Inamura, K.; Yokouchi, Y.; Kobayashi, M.; Sakakibara, R.; Ninomiya, H.; Subat, S.; Nagano, H.; Nomura, K.; Okumura, S.; Shibutani, T.; et al. Tumor B7-H3 (CD276) expression and smoking history in relation to lung adenocarcinoma prognosis. Lung Cancer 2017, 103, 44-51. [CrossRef] [PubMed]

17. Zhang, Y.; Li, Z.Y.; Hou, X.X.; Wang, X.; Luo, Y.H.; Ying, Y.P.; Chen, G. Clinical significance and effect of AEG-1 on the proliferation, invasion, and migration of NSCLC: A study based on immunohistochemistry, TCGA, bioinformatics, in vitro and in vivo verification. Oncotarget 2017, 8, 16531-16552. [CrossRef] [PubMed]

18. Inamura, K.; Yokouchi, Y.; Kobayashi, M.; Ninomiya, H.; Sakakibara, R.; Subat, S.; Nagano, H.; Nomura, K.; Okumura, S.; Shibutani, T.; et al. Association of tumor TROP2 expression with prognosis varies among lung cancer subtypes. Oncotarget 2017, 8, 28725-28735. [CrossRef] [PubMed]

19. Lynch, T.J.; Bell, D.W.; Sordella, R.; Gurubhagavatula, S.; Okimoto, R.A.; Brannigan, B.W.; Harris, P.L.; Haserlat, S.M.; Supko, J.G.; Haluska, F.G.; et al. Activating mutations in the epidermal growth factor receptor underlying responsiveness of non-small-cell lung cancer to gefitinib. N. Engl. J. Med. 2004, 350, 2129-2139. [CrossRef] [PubMed]

20. Kwak, E.L.; Bang, Y.J.; Camidge, D.R.; Shaw, A.T.; Solomon, B.; Maki, R.G.; Ou, S.H.; Dezube, B.J.; Janne, P.A.; Costa, D.B.; et al. Anaplastic lymphoma kinase inhibition in non-small-cell lung cancer. N. Engl. J. Med. 2010, 363, 1693-1703. [CrossRef] [PubMed]

21. Shaw, A.T.; Ou, S.H.; Bang, Y.J.; Camidge, D.R.; Solomon, B.J.; Salgia, R.; Riely, G.J.; Varella-Garcia, M.; Shapiro, G.I.; Costa, D.B.; et al. Crizotinib in ROS1-rearranged non-small-cell lung cancer. N. Engl. J. Med. 2014, 371, 1963-1971. [CrossRef] [PubMed] 
22. Garon, E.B.; Rizvi, N.A.; Hui, R.; Leighl, N.; Balmanoukian, A.S.; Eder, J.P.; Patnaik, A.; Aggarwal, C.; Gubens, M.; Horn, L.; et al. Pembrolizumab for the treatment of non-small-cell lung cancer. N. Engl. J. Med. 2015, 372, 2018-2028. [CrossRef] [PubMed]

23. Goldenberg, D.M.; Cardillo, T.M.; Govindan, S.V.; Rossi, E.A.; Sharkey, R.M. Trop-2 is a novel target for solid cancer therapy with sacituzumab govitecan (IMMU-132), an antibody-drug conjugate (ADC). Oncotarget 2015, 6, 22496-22512. [CrossRef] [PubMed]

24. Shaw, A.T.; Hsu, P.P.; Awad, M.M.; Engelman, J.A. Tyrosine kinase gene rearrangements in epithelial malignancies. Nat. Rev. Cancer 2013, 13, 772-787. [CrossRef] [PubMed]

25. Boolell, V.; Alamgeer, M.; Watkins, D.N.; Ganju, V. The Evolution of Therapies in Non-Small Cell Lung Cancer. Cancers (Basel) 2015, 7, 1815-1846. [CrossRef] [PubMed]

26. Rothschild, S.I. Targeted Therapies in Non-Small Cell Lung Cancer-Beyond EGFR and ALK. Cancers (Basel) 2015, 7, 930-949. [CrossRef] [PubMed]

27. Manchado, E.; Weissmueller, S.; Morris, J.P.T.; Chen, C.C.; Wullenkord, R.; Lujambio, A.; de Stanchina, E.; Poirier, J.T.; Gainor, J.F.; Corcoran, R.B.; et al. A combinatorial strategy for treating KRAS-mutant lung cancer. Nature 2016, 534, 647-651. [CrossRef] [PubMed]

28. Lu, J.; Getz, G.; Miska, E.A.; Alvarez-Saavedra, E.; Lamb, J.; Peck, D.; Sweet-Cordero, A.; Ebert, B.L.; Mak, R.H.; Ferrando, A.A.; et al. MicroRNA expression profiles classify human cancers. Nature 2005, 435, 834-838. [CrossRef] [PubMed]

29. Pasquinelli, A.E.; Reinhart, B.J.; Slack, F.; Martindale, M.Q.; Kuroda, M.I.; Maller, B.; Hayward, D.C.; Ball, E.E.; Degnan, B.; Muller, P.; et al. Conservation of the sequence and temporal expression of let-7 heterochronic regulatory RNA. Nature 2000, 408, 86-89. [PubMed]

30. He, L.; He, X.; Lim, L.P.; de Stanchina, E.; Xuan, Z.; Liang, Y.; Xue, W.; Zender, L.; Magnus, J.; Ridzon, D.; et al. A microRNA component of the p53 tumour suppressor network. Nature 2007, 447, 1130-1134. [CrossRef] [PubMed]

31. Takahashi, R.U.; Miyazaki, H.; Ochiya, T. The Roles of MicroRNAs in Breast Cancer. Cancers (Basel) 2015, 7, 598-616. [CrossRef] [PubMed]

32. Takahashi, R.U.; Miyazaki, H.; Takeshita, F.; Yamamoto, Y.; Minoura, K.; Ono, M.; Kodaira, M.; Tamura, K.; Mori, M.; Ochiya, T. Loss of microRNA-27b contributes to breast cancer stem cell generation by activating ENPP1. Nat. Commun. 2015, 6, 7318. [CrossRef] [PubMed]

33. Orellana, E.A.; Kasinski, A.L. MicroRNAs in Cancer: A Historical Perspective on the Path from Discovery to Therapy. Cancers (Basel) 2015, 7, 1388-1405. [CrossRef] [PubMed]

34. Frixa, T.; Donzelli, S.; Blandino, G. Oncogenic MicroRNAs: Key Players in Malignant Transformation. Cancers (Basel) 2015, 7, 2466-2485. [CrossRef] [PubMed]

35. Vaca, L. Point-of-care diagnostic tools to detect circulating microRNAS as biomarkers of disease. Sensors (Basel) 2014, 14, 9117-9131. [CrossRef] [PubMed]

36. Ajit, S.K. Circulating microRNAs as biomarkers, therapeutic targets, and signaling molecules. Sensors (Basel) 2012, 12, 3359-3369. [CrossRef] [PubMed]

37. Yanaihara, N.; Caplen, N.; Bowman, E.; Seike, M.; Kumamoto, K.; Yi, M.; Stephens, R.M.; Okamoto, A.; Yokota, J.; Tanaka, T.; et al. Unique microRNA molecular profiles in lung cancer diagnosis and prognosis. Cancer Cell 2006, 9, 189-198. [CrossRef] [PubMed]

38. Yu, S.L.; Chen, H.Y.; Chang, G.C.; Chen, C.Y.; Chen, H.W.; Singh, S.; Cheng, C.L.; Yu, C.J.; Lee, Y.C.; Chen, H.S.; et al. MicroRNA signature predicts survival and relapse in lung cancer. Cancer Cell 2008, 13, 48-57. [CrossRef] [PubMed]

39. Inamura, K.; Ishikawa, Y. MicroRNA In Lung Cancer: Novel Biomarkers and Potential Tools for Treatment. J. Clin. Med. 2016, 5, 36. [CrossRef] [PubMed]

40. MacDonagh, L.; Gray, S.G.; Finn, S.P.; Cuffe, S.; O’Byrne, K.J.; Barr, M.P. The emerging role of microRNAs in resistance to lung cancer treatments. Cancer Treat Rev. 2015, 41, 160-169. [CrossRef] [PubMed]

41. Chen, J.; Wang, R.; Zhang, K.; Chen, L.B. Long non-coding RNAs in non-small cell lung cancer as biomarkers and therapeutic targets. J. Cell Mol. Med. 2014, 18, 2425-2436. [CrossRef] [PubMed]

42. Wei, M.M.; Zhou, G.B. Long Non-coding RNAs and Their Roles in Non-small-cell Lung Cancer. Genom. Proteom. Bioinform. 2016, 14, 280-288. [CrossRef] [PubMed]

43. Xu, Y.J.; Du, Y.; Fan, Y. Long noncoding RNAs in lung cancer: What we know in 2015. Clin. Transl. Oncol. 2016, 18, 660-665. [CrossRef] [PubMed] 
44. Ricciuti, B.; Mencaroni, C.; Paglialunga, L.; Paciullo, F.; Crino, L.; Chiari, R.; Metro, G. Long noncoding RNAs: New insights into non-small cell lung cancer biology, diagnosis and therapy. Med. Oncol. 2016, 33, 18. [CrossRef] [PubMed]

45. Booton, R.; Lindsay, M.A. Emerging role of MicroRNAs and long noncoding RNAs in respiratory disease. Chest 2014, 146, 193-204. [CrossRef] [PubMed]

46. Matikas, A.; Syrigos, K.N.; Agelaki, S. Circulating Biomarkers in Non-Small-Cell Lung Cancer: Current Status and Future Challenges. Clin. Lung Cancer 2016, 17, 507-516. [CrossRef] [PubMed]

47. Murlidhar, V.; Ramnath, N.; Nagrath, S.; Reddy, R.M. Optimizing the Detection of Circulating Markers to Aid in Early Lung Cancer Detection. Cancers (Basel) 2016, 8, 61. [CrossRef] [PubMed]

48. Kunz, M.; Wolf, B.; Schulze, H.; Atlan, D.; Walles, T.; Walles, H.; Dandekar, T. Non-Coding RNAs in Lung Cancer: Contribution of Bioinformatics Analysis to the Development of Non-Invasive Diagnostic Tools. Genes (Basel) 2017, 8, 8. [CrossRef] [PubMed]

49. Zhao, C.; Lu, F.; Chen, H.; Zhao, F.; Zhu, Z.; Zhao, X.; Chen, H. Clinical significance of circulating miRNA detection in lung cancer. Med. Oncol. 2016, 33, 41. [CrossRef] [PubMed]

50. ENCODE Project Consortium. An integrated encyclopedia of DNA elements in the human genome. Nature 2012, 489, 57-74.

51. Djebali, S.; Davis, C.A.; Merkel, A.; Dobin, A.; Lassmann, T.; Mortazavi, A.; Tanzer, A.; Lagarde, J.; Lin, W.; Schlesinger, F.; et al. Landscape of transcription in human cells. Nature 2012, 489, 101-108. [CrossRef] [PubMed]

52. Bartel, D.P. MicroRNAs: Genomics, biogenesis, mechanism, and function. Cell 2004, 116, 281-297. [CrossRef]

53. Xiao, Z.D.; Zhuang, L.; Gan, B. Long non-coding RNAs in cancer metabolism. Bioessays 2016, 38, 991-996. [CrossRef] [PubMed]

54. Liu, X.; Xiao, Z.D.; Han, L.; Zhang, J.; Lee, S.W.; Wang, W.; Lee, H.; Zhuang, L.; Chen, J.; Lin, H.K.; et al. LncRNA NBR2 engages a metabolic checkpoint by regulating AMPK under energy stress. Nat. Cell Biol. 2016, 18, 431-442. [CrossRef] [PubMed]

55. Peng, H.; Wang, J.; Li, J.; Zhao, M.; Huang, S.K.; Gu, Y.Y.; Li, Y.; Sun, X.J.; Yang, L.; Luo, Q.; et al. A circulating non-coding RNA panel as an early detection predictor of non-small cell lung cancer. Life Sci. 2016, 151, 235-242. [CrossRef] [PubMed]

56. Shi, T.; Gao, G.; Cao, Y. Long Noncoding RNAs as Novel Biomarkers Have a Promising Future in Cancer Diagnostics. Dis. Markers 2016, 2016, 9085195. [CrossRef] [PubMed]

57. Shen, Y.; Tian, F.; Chen, Z.; Li, R.; Ge, Q.; Lu, Z. Amplification-based method for microRNA detection. Biosens. Bioelectron. 2015, 71, 322-331. [CrossRef] [PubMed]

58. Takamizawa, J.; Konishi, H.; Yanagisawa, K.; Tomida, S.; Osada, H.; Endoh, H.; Harano, T.; Yatabe, Y.; Nagino, M.; Nimura, Y.; et al. Reduced expression of the let-7 microRNAs in human lung cancers in association with shortened postoperative survival. Cancer Res. 2004, 64, 3753-3756. [CrossRef] [PubMed]

59. Inamura, K.; Togashi, Y.; Nomura, K.; Ninomiya, H.; Hiramatsu, M.; Satoh, Y.; Okumura, S.; Nakagawa, K.; Ishikawa, Y. let-7 microRNA expression is reduced in bronchioloalveolar carcinoma, a non-invasive carcinoma, and is not correlated with prognosis. Lung Cancer 2007, 58, 392-396. [CrossRef] [PubMed]

60. Johnson, S.M.; Grosshans, H.; Shingara, J.; Byrom, M.; Jarvis, R.; Cheng, A.; Labourier, E.; Reinert, K.L.; Brown, D.; Slack, F.J. RAS is regulated by the let-7 microRNA family. Cell 2005, 120, 635-647. [CrossRef] [PubMed]

61. Johnson, C.D.; Esquela-Kerscher, A.; Stefani, G.; Byrom, M.; Kelnar, K.; Ovcharenko, D.; Wilson, M.; Wang, X.; Shelton, J.; Shingara, J.; et al. The let-7 microRNA represses cell proliferation pathways in human cells. Cancer Res. 2007, 67, 7713-7722. [CrossRef] [PubMed]

62. Tokumaru, S.; Suzuki, M.; Yamada, H.; Nagino, M.; Takahashi, T. let-7 regulates Dicer expression and constitutes a negative feedback loop. Carcinogenesis 2008, 29, 2073-2077. [CrossRef] [PubMed]

63. Zhou, Y.; Liang, H.; Liao, Z.; Wang, Y.; Hu, X.; Chen, X.; Xu, L.; Hu, Z. miR-203 enhances let-7 biogenesis by targeting LIN28B to suppress tumor growth in lung cancer. Sci. Rep. 2017, 7, 42680. [CrossRef] [PubMed]

64. Bommer, G.T.; Gerin, I.; Feng, Y.; Kaczorowski, A.J.; Kuick, R.; Love, R.E.; Zhai, Y.; Giordano, T.J.; Qin, Z.S.; Moore, B.B.; et al. p53-mediated activation of miRNA34 candidate tumor-suppressor genes. Curr. Biol. 2007, 17, 1298-1307. [CrossRef] [PubMed] 
65. Kasinski, A.L.; Slack, F.J. miRNA-34 prevents cancer initiation and progression in a therapeutically resistant K-ras and p53-induced mouse model of lung adenocarcinoma. Cancer Res. 2012, 72, 5576-5587. [CrossRef] [PubMed]

66. Garofalo, M.; Jeon, Y.J.; Nuovo, G.J.; Middleton, J.; Secchiero, P.; Joshi, P.; Alder, H.; Nazaryan, N.; Di Leva, G.; Romano, G.; et al. MiR-34a/c-Dependent PDGFR-alpha/beta Downregulation Inhibits Tumorigenesis and Enhances TRAIL-Induced Apoptosis in Lung Cancer. PLoS ONE 2013, 8, e67581. [CrossRef] [PubMed]

67. Cortez, M.A.; Ivan, C.; Valdecanas, D.; Wang, X.; Peltier, H.J.; Ye, Y.; Araujo, L.; Carbone, D.P.; Shilo, K.; Giri, D.K.; et al. PDL1 Regulation by p53 via miR-34. J. Natl. Cancer Inst. 2015, 108. [CrossRef] [PubMed]

68. Ceppi, P.; Mudduluru, G.; Kumarswamy, R.; Rapa, I.; Scagliotti, G.V.; Papotti, M.; Allgayer, H. Loss of miR-200c expression induces an aggressive, invasive, and chemoresistant phenotype in non-small cell lung cancer. Mol. Cancer Res. 2010, 8, 1207-1216. [CrossRef] [PubMed]

69. Takeyama, Y.; Sato, M.; Horio, M.; Hase, T.; Yoshida, K.; Yokoyama, T.; Nakashima, H.; Hashimoto, N.; Sekido, Y.; Gazdar, A.F.; et al. Knockdown of ZEB1, a master epithelial-to-mesenchymal transition (EMT) gene, suppresses anchorage-independent cell growth of lung cancer cells. Cancer Lett. 2010, 296, 216-224. [CrossRef] [PubMed]

70. Zhang, N.; Liu, Y.; Wang, Y.; Zhao, M.; Tu, L.; Luo, F. Decitabine reverses TGF-beta1-induced epithelial-mesenchymal transition in non-small-cell lung cancer by regulating miR-200/ZEB axis. Drug Des. Devel. Ther. 2017, 11, 969-983. [CrossRef] [PubMed]

71. Song, L.; Li, D.; Gu, Y.; Wen, Z.M.; Jie, J.; Zhao, D.; Peng, L.P. MicroRNA-126 Targeting PIK3R2 Inhibits NSCLC A549 Cell Proliferation, Migration, and Invasion by Regulation of PTEN/PI3K/AKT Pathway. Clin. Lung Cancer 2016, 17, e65-e75. [CrossRef] [PubMed]

72. An, Q.; Han, C.; Zhou, Y.; Li, F.; Li, D.; Zhang, X.; Yu, Z.; Duan, Z.; Kan, Q. Matrine induces cell cycle arrest and apoptosis with recovery of the expression of miR-126 in the A549 non-small cell lung cancer cell line. Mol. Med. Rep. 2016, 14, 4042-4048. [CrossRef] [PubMed]

73. Liu, B.; Qu, J.; Xu, F.; Guo, Y.; Wang, Y.; Yu, H.; Qian, B. MiR-195 suppresses non-small cell lung cancer by targeting CHEK1. Oncotarget 2015, 6, 9445-9456. [CrossRef] [PubMed]

74. Yang, M.; Shen, H.; Qiu, C.; Ni, Y.; Wang, L.; Dong, W.; Liao, Y.; Du, J. High expression of miR-21 and miR-155 predicts recurrence and unfavourable survival in non-small cell lung cancer. Eur. J. Cancer 2013, 49, 604-615. [CrossRef] [PubMed]

75. Zhang, J.G.; Wang, J.J.; Zhao, F.; Liu, Q.; Jiang, K.; Yang, G.H. MicroRNA-21 (miR-21) represses tumor suppressor PTEN and promotes growth and invasion in non-small cell lung cancer (NSCLC). Clin. Chim. Acta 2010, 411, 846-852. [CrossRef] [PubMed]

76. Bhatti, I.; Lee, A.; James, V.; Hall, R.I.; Lund, J.N.; Tufarelli, C.; Lobo, D.N.; Larvin, M. Knockdown of microRNA-21 inhibits proliferation and increases cell death by targeting programmed cell death 4 (PDCD4) in pancreatic ductal adenocarcinoma. J. Gastrointest. Surg. 2011, 15, 199-208. [CrossRef] [PubMed]

77. Zhu, S.; Wu, H.; Wu, F.; Nie, D.; Sheng, S.; Mo, Y.Y. MicroRNA-21 targets tumor suppressor genes in invasion and metastasis. Cell Res. 2008, 18, 350-359. [CrossRef] [PubMed]

78. Xue, X.; Liu, Y.; Wang, Y.; Meng, M.; Wang, K.; Zang, X.; Zhao, S.; Sun, X.; Cui, L.; Pan, L.; et al. MiR-21 and MiR-155 promote non-small cell lung cancer progression by downregulating SOCS1, SOCS6, and PTEN. Oncotarget 2016, 7, 84508-84519. [CrossRef] [PubMed]

79. Wei, J.; Gao, W.; Zhu, C.J.; Liu, Y.Q.; Mei, Z.; Cheng, T.; Shu, Y.Q. Identification of plasma microRNA-21 as a biomarker for early detection and chemosensitivity of non-small cell lung cancer. Chin. J. Cancer 2011, 30, 407-414. [CrossRef] [PubMed]

80. Ma, Y.; Xia, H.; Liu, Y.; Li, M. Silencing miR-21 sensitizes non-small cell lung cancer A549 cells to ionizing radiation through inhibition of PI3K/Akt. Biomed. Res. Int. 2014, 2014, 617868. [CrossRef] [PubMed]

81. Shen, K.H.; Hung, J.H.; Chang, C.W.; Weng, Y.T.; Wu, M.J.; Chen, P.S. Solasodine inhibits invasion of human lung cancer cell through downregulation of miR-21 and MMPs expression. Chem. Biol. Interact. 2017, 268, 129-135. [CrossRef] [PubMed]

82. Li, X.; Zang, A.; Jia, Y.; Zhang, J.; Fan, W.; Feng, J.; Duan, M.; Zhang, L.; Huo, R.; Jiao, J.; et al. Triptolide reduces proliferation and enhances apoptosis of human non-small cell lung cancer cells through PTEN by targeting miR-21. Mol. Med. Rep. 2016, 13, 2763-2768. [CrossRef] [PubMed] 
83. Lv, X.; Yao, L.; Zhang, J.; Han, P.; Li, C. Inhibition of microRNA-155 sensitizes lung cancer cells to irradiation via suppression of HK2-modulated glucose metabolism. Mol. Med. Rep. 2016, 14, 1332-1338. [CrossRef] [PubMed]

84. Lv, L.; An, X.; Li, H.; Ma, L. Effect of miR-155 knockdown on the reversal of doxorubicin resistance in human lung cancer A549/dox cells. Oncol. Lett. 2016, 11, 1161-1166. [CrossRef] [PubMed]

85. Van Roosbroeck, K.; Fanini, F.; Setoyama, T.; Ivan, C.; Rodriguez-Aguayo, C.; Fuentes-Mattei, E.; Xiao, L.; Vannini, I.; Redis, R.; D'Abundo, L.; et al. Combining anti-miR-155 with chemotherapy for the treatment of lung cancers. Clin. Cancer Res. 2016. [CrossRef] [PubMed]

86. Hayashita, Y.; Osada, H.; Tatematsu, Y.; Yamada, H.; Yanagisawa, K.; Tomida, S.; Yatabe, Y.; Kawahara, K.; Sekido, Y.; Takahashi, T. A polycistronic microRNA cluster, miR-17-92, is overexpressed in human lung cancers and enhances cell proliferation. Cancer Res. 2005, 65, 9628-9632. [CrossRef] [PubMed]

87. Matsubara, H.; Takeuchi, T.; Nishikawa, E.; Yanagisawa, K.; Hayashita, Y.; Ebi, H.; Yamada, H.; Suzuki, M.; Nagino, M.; Nimura, Y.; et al. Apoptosis induction by antisense oligonucleotides against miR-17-5p and miR-20a in lung cancers overexpressing miR-17-92. Oncogene 2007, 26, 6099-6105. [CrossRef] [PubMed]

88. Osada, H.; Takahashi, T. let-7 and miR-17-92: Small-sized major players in lung cancer development. Cancer Sci. 2011, 102, 9-17. [CrossRef] [PubMed]

89. Li, L.; Song, W.; Yan, X.; Li, A.; Zhang, X.; Li, W.; Zhou, X.W.L.; Yu, D.; Hu, J.F.; Cui, J. Friend leukemia virus integration 1 promotes tumorigenesis of small cell lung cancer cells by activating the miR-17-92 pathway. Oncotarget 2017, in press. [CrossRef] [PubMed]

90. Garofalo, M.; Romano, G.; Di Leva, G.; Nuovo, G.; Jeon, Y.J.; Ngankeu, A.; Sun, J.; Lovat, F.; Alder, H.; Condorelli, G.; et al. EGFR and MET receptor tyrosine kinase-altered microRNA expression induces tumorigenesis and gefitinib resistance in lung cancers. Nat. Med. 2011, 18, 74-82. [CrossRef] [PubMed]

91. Garofalo, M.; Quintavalle, C.; Di Leva, G.; Zanca, C.; Romano, G.; Taccioli, C.; Liu, C.G.; Croce, C.M.; Condorelli, G. MicroRNA signatures of TRAIL resistance in human non-small cell lung cancer. Oncogene 2008, 27, 3845-3855. [CrossRef] [PubMed]

92. Garofalo, M.; Di Leva, G.; Romano, G.; Nuovo, G.; Suh, S.S.; Ngankeu, A.; Taccioli, C.; Pichiorri, F.; Alder, H.; Secchiero, P.; et al. miR-221\&222 regulate TRAIL resistance and enhance tumorigenicity through PTEN and TIMP3 downregulation. Cancer Cell 2009, 16, 498-509. [PubMed]

93. Yu, M.; Liang, H.; Fu, Z.; Wang, X.; Liao, Z.; Zhou, Y.; Liu, Y.; Wang, Y.; Hong, Y.; Zhou, X.; et al. BAP1 suppresses lung cancer progression and is inhibited by miR-31. Oncotarget 2016, 7, 13742-13753. [PubMed]

94. Edmonds, M.D.; Boyd, K.L.; Moyo, T.; Mitra, R.; Duszynski, R.; Arrate, M.P.; Chen, X.; Zhao, Z.; Blackwell, T.S.; Andl, T.; et al. MicroRNA-31 initiates lung tumorigenesis and promotes mutant KRAS-driven lung cancer. J. Clin. Investig. 2016, 126, 349-364. [CrossRef] [PubMed]

95. Xu, H.; Ma, J.; Zheng, J.; Wu, J.; Qu, C.; Sun, F.; Xu, S. MiR-31 Functions as a Tumor Suppressor in Lung Adenocarcinoma Mainly by Targeting HuR. Clin. Lab. 2016, 62, 711-718. [CrossRef] [PubMed]

96. Okudela, K.; Suzuki, T.; Umeda, S.; Tateishi, Y.; Mitsui, H.; Miyagi, Y.; Ohashi, K. A comprehensive search for microRNAs with expression profiles modulated by oncogenic KRAS: Potential involvement of miR-31 in lung carcinogenesis. Oncol. Rep. 2014, 32, 1374-1384. [CrossRef] [PubMed]

97. Zhou, Y.; Zhong, Y.; Wang, Y.; Zhang, X.; Batista, D.L.; Gejman, R.; Ansell, P.J.; Zhao, J.; Weng, C.; Klibanski, A. Activation of p53 by MEG3 non-coding RNA. J. Biol. Chem. 2007, 282, 24731-24742. [CrossRef] [PubMed]

98. Lu, K.H.; Li, W.; Liu, X.H.; Sun, M.; Zhang, M.L.; Wu, W.Q.; Xie, W.P.; Hou, Y.Y. Long non-coding RNA MEG3 inhibits NSCLC cells proliferation and induces apoptosis by affecting p53 expression. BMC Cancer 2013, 13, 461. [CrossRef] [PubMed]

99. Sun, L.; Li, Y.; Yang, B. Downregulated long non-coding RNA MEG3 in breast cancer regulates proliferation, migration and invasion by depending on p53's transcriptional activity. Biochem. Biophys. Res. Commun. 2016, 478, 323-329. [CrossRef] [PubMed]

100. Han, L.; Kong, R.; Yin, D.D.; Zhang, E.B.; Xu, T.P.; De, W.; Shu, Y.Q. Low expression of long noncoding RNA GAS6-AS1 predicts a poor prognosis in patients with NSCLC. Med. Oncol. 2013, 30, 694. [CrossRef] [PubMed]

101. Sun, M.; Liu, X.H.; Wang, K.M.; Nie, F.Q.; Kong, R.; Yang, J.S.; Xia, R.; Xu, T.P.; Jin, F.Y.; Liu, Z.J.; et al. Downregulation of BRAF activated non-coding RNA is associated with poor prognosis for non-small cell lung cancer and promotes metastasis by affecting epithelial-mesenchymal transition. Mol. Cancer 2014, 13, 68. [CrossRef] [PubMed] 
102. Han, L.; Zhang, E.B.; Yin, D.D.; Kong, R.; Xu, T.P.; Chen, W.M.; Xia, R.; Shu, Y.Q.; De, W. Low expression of long noncoding RNA PANDAR predicts a poor prognosis of non-small cell lung cancer and affects cell apoptosis by regulating Bcl-2. Cell Death Dis. 2015, 6, e1665. [CrossRef] [PubMed]

103. Weber, D.G.; Johnen, G.; Casjens, S.; Bryk, O.; Pesch, B.; Jockel, K.H.; Kollmeier, J.; Bruning, T. Evaluation of long noncoding RNA MALAT1 as a candidate blood-based biomarker for the diagnosis of non-small cell lung cancer. BMC Res. Notes 2013, 6, 518. [CrossRef] [PubMed]

104. Ji, P.; Diederichs, S.; Wang, W.; Boing, S.; Metzger, R.; Schneider, P.M.; Tidow, N.; Brandt, B.; Buerger, H.; Bulk, E.; et al. MALAT-1, a novel noncoding RNA, and thymosin beta4 predict metastasis and survival in early-stage non-small cell lung cancer. Oncogene 2003, 22, 8031-8041. [CrossRef] [PubMed]

105. Schmidt, L.H.; Spieker, T.; Koschmieder, S.; Schaffers, S.; Humberg, J.; Jungen, D.; Bulk, E.; Hascher, A.; Wittmer, D.; Marra, A.; et al. The long noncoding MALAT-1 RNA indicates a poor prognosis in non-small cell lung cancer and induces migration and tumor growth. J. Thorac. Oncol. 2011, 6, 1984-1992. [CrossRef] [PubMed]

106. Tripathi, V.; Shen, Z.; Chakraborty, A.; Giri, S.; Freier, S.M.; Wu, X.; Zhang, Y.; Gorospe, M.; Prasanth, S.G.; Lal, A.; et al. Long noncoding RNA MALAT1 controls cell cycle progression by regulating the expression of oncogenic transcription factor B-MYB. PLoS Genet. 2013, 9, e1003368. [CrossRef] [PubMed]

107. Wang, J.Z.; Xiang, J.J.; Wu, L.G.; Bai, Y.S.; Chen, Z.W.; Yin, X.Q.; Wang, Q.; Guo, W.H.; Peng, Y.; Guo, H.; et al. A genetic variant in long non-coding RNA MALAT1 associated with survival outcome among patients with advanced lung adenocarcinoma: A survival cohort analysis. BMC Cancer 2017, 17, 167. [CrossRef] [PubMed]

108. Rinn, J.L.; Kertesz, M.; Wang, J.K.; Squazzo, S.L.; Xu, X.; Brugmann, S.A.; Goodnough, L.H.; Helms, J.A.; Farnham, P.J.; Segal, E.; et al. Functional demarcation of active and silent chromatin domains in human HOX loci by noncoding RNAs. Cell 2007, 129, 1311-1323. [CrossRef] [PubMed]

109. Gupta, R.A.; Shah, N.; Wang, K.C.; Kim, J.; Horlings, H.M.; Wong, D.J.; Tsai, M.C.; Hung, T.; Argani, P.; Rinn, J.L.; et al. Long non-coding RNA HOTAIR reprograms chromatin state to promote cancer metastasis. Nature 2010, 464, 1071-1076. [CrossRef] [PubMed]

110. Liu, Z.; Sun, M.; Lu, K.; Liu, J.; Zhang, M.; Wu, W.; De, W.; Wang, Z.; Wang, R. The long noncoding RNA HOTAIR contributes to cisplatin resistance of human lung adenocarcinoma cells via downregualtion of p21(WAF1/CIP1) expression. PLoS ONE 2013, 8, e77293.

111. Liu, M.Y.; Li, X.Q.; Gao, T.H.; Cui, Y.; Ma, N.; Zhou, Y.; Zhang, G.J. Elevated HOTAIR expression associated with cisplatin resistance in non-small cell lung cancer patients. J. Thorac. Dis. 2016, 8, 3314-3322. [CrossRef] [PubMed]

112. Qiu, M.; Xu, Y.; Yang, X.; Wang, J.; Hu, J.; Xu, L.; Yin, R. CCAT2 is a lung adenocarcinoma-specific long non-coding RNA and promotes invasion of non-small cell lung cancer. Tumour. Biol. 2014, 35, 5375-5380. [CrossRef] [PubMed]

113. Ling, H.; Spizzo, R.; Atlasi, Y.; Nicoloso, M.; Shimizu, M.; Redis, R.S.; Nishida, N.; Gafa, R.; Song, J.; Guo, Z.; et al. CCAT2, a novel noncoding RNA mapping to 8q24, underlies metastatic progression and chromosomal instability in colon cancer. Genome Res. 2013, 23, 1446-1461. [CrossRef] [PubMed]

114. Zhao, Z.; Wang, J.; Wang, S.; Chang, H.; Zhang, T.; Qu, J. LncRNA CCAT2 promotes tumorigenesis by over-expressed Pokemon in non-small cell lung cancer. Biomed. Pharmacother. 2017, 87, 692-697. [CrossRef] [PubMed]

(C) 2017 by the author. Licensee MDPI, Basel, Switzerland. This article is an open access article distributed under the terms and conditions of the Creative Commons Attribution (CC BY) license (http://creativecommons.org/licenses/by/4.0/). 